\title{
Treatment of Surface Treatment Effluents by Electrocoagulation Process Using Aluminium Electrodes
}

\author{
Soukaina Namoussi ${ }^{1 *}$, Chaimaa Merbouh', Mohamed Kabriti', \\ Abdelmottalib Nahli', Ayoub Naamane ${ }^{1}$, Mohamed Chlaida' ${ }^{1}$, Nadia lounes ${ }^{1}$ \\ 1 Laboratory of Ecology and Environment (LEE), Faculty of Sciences Ben M'Scik, University Hassan II, \\ BP 7955-Sidi Othmane, Casablanca, Morocco \\ 2 National Laboratory for Studies and Pollution Monitoring (LNESP), Rabat, Morocco \\ * Corresponding author's e-mail: soukaina.env@gmail.com
}

\begin{abstract}
The surface treatment industry generates effluents with a high load of highly toxic chemicals which must be treated under increasingly stringent regulation. The aim of this study was to treat the effluents of surface treatment unit of an aeronautical industry by the electrocoagulation process using aluminium electrodes. This process is used to study the performance to remove colloidal load, significant amount of oxidizable material and high levels of

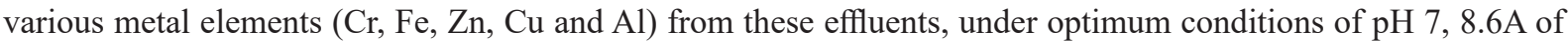
current intensity and $60 \mathrm{~min}$ of application. The electrocoagulation process was found to be effective in reducing turbidity (97.12\%), COD (97.5\%), SS (97.84\%) and conductivity $(96.82 \%)$, hexavalent chromium $(99.99 \%), \mathrm{Zn}$ (96.82\%), $\mathrm{Cu}(94.3 \%)$, Iron (99.9\%), Al (91.96\%). The treated effluent conformed to the Moroccan standards of surface treatment discharge.
\end{abstract}

Keywords: Electrocoagulation, aluminium electrodes, surface treatment, effluents, pollutants

\section{INTRODUCTION}

The industrial sector is considered to be one of the most polluting in terms of discharges into aquatic environments, because it uses large amounts of water in manufacturing processes as well as chemicals through various commercial formulations, which could damage the local sanitation network as well as the equipment of the urban wastewater treatment plants to which these industries are connected. There is also a risk of contamination of water resources, both surface and ground (Bouderka et al., 2016) or even marine resources (Ayah et al., 2015: Siba et al., 2018) and coastal areas (Izougarhane et al., 2016). Among industrial sectors, the surface treatment sector (ST), because they use many chemicals, in particular metals and organic substances, known to be toxic to humans and the environment (Elise Euvrard., 2017). The major problem with this type of effluent lies in the fact that they are not always treated by the majority of industries and can affect the local sanitation network or even the equipment of centralized wastewater treatment plants. Indeed, the results obtained by the characterization show that this effluent contains hexavalent chromium, well known for its toxicity (Brignon et al., 2015). The effluent has other characteristics, such as a high concentration of COD, suspended solids (SS) and heavy metals ( $\mathrm{Al}, \mathrm{Zn}, \mathrm{Cu}, \mathrm{Fe}$, etc.). Because of their environmental toxicity (Rabia et al., 2019), these industrial effluents must be treated in accordance with the limit values set by national standards for discharge into the sewer or into the environment (AVLRBG.,2010: 1oi ${ }^{\circ}$ 10-95.,1995). The objective of this study was to apply a treatment of the effluents generated by this activity by electrocoagulation (EC). This electrochemical technique is commonly used in the treatment of water and industrial effluents (Mickova et al., 2015), the treatment of surface 
water (Bejjany et al., 2017), the treatment of sulphated salinity and the associated toxicity of mining effluents (FOUDHAILI.,2019), the elimination nickel in wastewater (Jerroumi et al., 2019), treatment of textile effluents (Yibor et al.,2021), treatment of peat water (Rusdianasari et al., 2019), purification of river water (Suryaningsih et al., 2021). Electrocoagulation technology is a simple, and more economical than conventional chemical treatment (Crini et al.,2019) contains less water and is more stable than those obtained by using the classical chemical coagulation method (Tlaiaa et al., 2020), because it is able to simultaneously eliminate a very wide variety of pollutants. These include, inter alia, colloidal particles, suspended particles, turbidity, heavy metals (El-Naas et al., 2013). This process is characterized by simple equipment and easy operation (Copra et al., 2012). The factors influencing the performance of the EC process depend on various parameters, such as the electrode material type, current intensity, inter-electrode distance, $\mathrm{pH}$ and treatment time (Alam et al., 2021).

\section{Electrocoagulation mechanisms}

The electrocoagulation process is based on the principle of soluble anodes in an electrocoagulation reactor which is composed of an electrochemical cell, in which cathodic metal electrodes immersed in the solution to be treated and connected externally to a direct current supply and sacrificial metal anodes are used to treat wastewater (Fayad, 2018).

For aluminum oxidation in an electrolytic system, aluminum hydroxide, $\mathrm{Al}(\mathrm{OH}) \mathrm{n}$, is produced, where $n=3$. At the anode: electro-dissolution of the anode leads to the release of the soluble $\mathrm{Al}^{3+}$ cations in the clay suspension according to the mechanism of the reaction (equation 1) (Bejjany et al., 2017).

$$
A l(s) \rightarrow A l 3+(a q)+3 e-
$$

The $\mathrm{Al}^{3+}$ ions thus produced undergo spontaneous hydrolysis reactions leading to the formation of several monomeric species as $\mathrm{Al}(\mathrm{OH})_{3}$, and optionally its polymers. They are coagulants, the $\mathrm{pH}$ of which ranges between 4 and 9 (Hakizimana, 2017).

Other reactions, called secondary reactions, may take place at the anode, particularly the generation of oxygen when the anodic potential is high. At the cathode: The water reduction reaction occurs, which results in the generation of hydrogen bubbles on its surface (equation 2):

$$
2 \mathrm{H}_{2} \mathrm{O}+2 \mathrm{e}-\rightarrow \mathrm{H}_{2}+2 \mathrm{OH}^{-}
$$

Freshly formed amorphous $\mathrm{Al}(\mathrm{OH})_{3}$ hydroxides have large surfaces which are beneficial for rapid adsorption different soluble pollutants and trapping of colloidal particles (Bharath et al., 2018). In this work, the electrocoagulation technique was used to decontaminate raw effluent of the surface treatment process of aeronautical parts.

\section{MATERIALS AND METHODS}

During this study, the experiments were performed in the laboratory using a rectangular electrocoagulation cell with a capacity of $1.5 \mathrm{~L}$ and a size of $15 \mathrm{~cm}$ long, $10 \mathrm{~cm}$ wide and $12 \mathrm{~cm}$ high (Figure 2). The electrodes are made of aluminium with a width of $8 \mathrm{~cm}$, a length of $12.5 \mathrm{~cm}$ and a thickness of $1 \mathrm{~mm}$, after several studies, it turned out that the treatment efficiency changes with the change of the distance between the electrodes. The work of Copra et al. (2012) showed that the treatment is effective with an inter-electrode distance of $2.5 \mathrm{~cm}$ while Balark et al. (2019) found that the distance of $2.5 \mathrm{~cm}$ is the most efficient. In turn, the work of Dindas et al. (2020) showed that the inter-electrode distance of $2 \mathrm{~cm}$ is the most efficient. This is why the electrodes were separated in parallel with a distance of $2 \mathrm{~cm}$ one from the other. The electrodes are connected to a digital DC power supply, capable of supplying an adjustable current intensity in the range of $0-10$ A (Long Wei Instruments). The samples treated by electrocoagulation were collected after 15 minutes of decantation and filtered through the filtration equipment to remove undissolved flocs.

In order to achieve the objectives, set in terms of effective and complete treatment of pollutants, the influence of the operating parameters of this electrocoagulation system (amperage, electrocoagulation time and $\mathrm{pH}$ ) and the effluent quality status were monitored through the measurements of physicochemical parameters (COD, SS, conductivity, turbidity, heavy metals $\left(\mathrm{Cr}^{6+} \mathrm{Zn}, \mathrm{Al}, \mathrm{Fe}, \mathrm{Cu}\right)$. During this 


\section{Power generator}

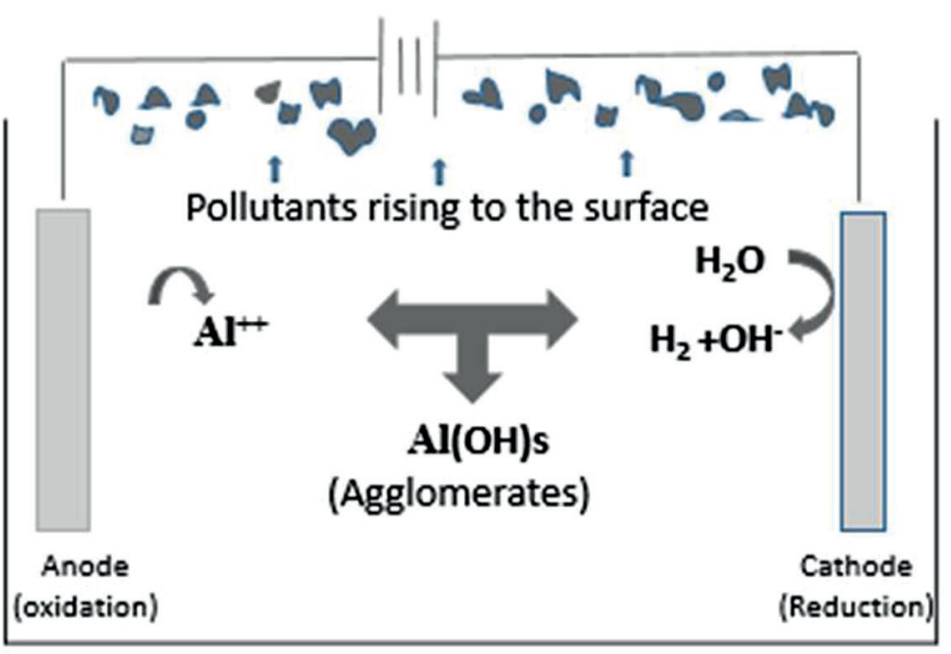

Fig. 1. Principle of electrocoagulation

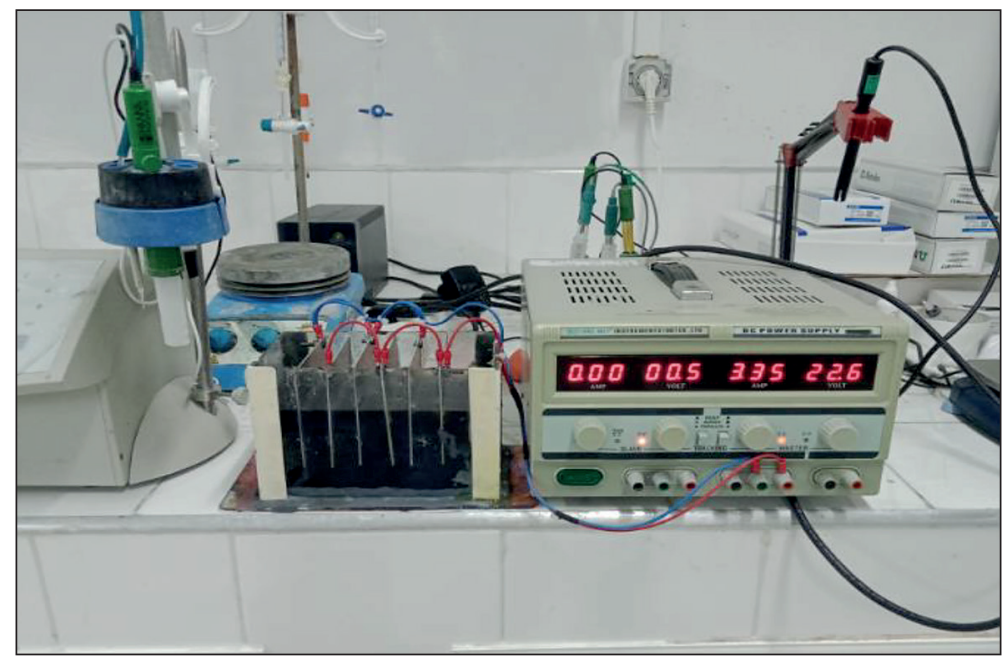

Fig. 2. Experimental system of electrocoagulation

study, the samples were taken from the four production lines in full operation and during the various production cycles. This sampling is carried out in a place where there is sufficient turbulence / agitation to ensure the homogeneity of the sample, an average of the 3 values obtained following the measurements and analysis before each experimental test was carried out. Table 1 presents the monitoring and measurement methods used in this study.

These electrocoagulation treatment tests were conducted under variable conditions of $\mathrm{pH}$ (4, 7 and 10), current intensity (2.8 A, 5.7 A and $8.6 \mathrm{~A}$ ) and for an overall period of $60 \mathrm{~min}$ with different treatment controls at $20 \mathrm{~min}, 30 \mathrm{~min}$, $40 \mathrm{~min}$ and $60 \mathrm{~min}$.

\section{RESULTS AND DISCUSSION}

\section{Physicochemical characteristics of the raw effluent}

The results of characteristics of the investigated wastewater (conductivity, turbidity, $\mathrm{pH}$, $\mathrm{COD}, \mathrm{SS}, \mathrm{Cr}, \mathrm{Zn}, \mathrm{Al}, \mathrm{Fe}$ and $\mathrm{Cu}$ ) are shown in Table 2.

The analysis of the effluent composition revealed a colloidal pollution (turbidity $=98 \mathrm{NTU}$ ), a significant oxidizable charge $(\mathrm{COD}=587 \mathrm{mg} / \mathrm{l})$, suspended solids $(663 \mathrm{mg} / \mathrm{l})$, a mixture of different metallic ( $\mathrm{Zn}, \mathrm{Al}, \mathrm{Fe}, \mathrm{Cu})$ and a high chromium concentration. These effluents do not comply with the Moroccan standard for surface treatment discharges (AVLRBG., 2010). 
Table 1. Parameters, materials and method

\begin{tabular}{|l|l|l|}
\hline \multicolumn{1}{|c|}{ Parameter } & \multicolumn{1}{c|}{ Material } & Device reference or analytical method \\
\hline Temperature $\left({ }^{\circ} \mathrm{C}\right)$ & Thermometer & TH CA 004 \\
\hline $\mathrm{pH}$ & $\mathrm{pH}$ meter & pH 3310 SET 2 \\
\hline Chemical Oxygen Demand "COD" $\left(\mathrm{mg} \cdot \mathrm{L}^{-1}\right)$ & Thermoreactor with kits type DCO10119 & Methode DIN ISO 15705 \\
\hline Turbidity (NTU) & Turbidity meter & EUTECH TN-100 \\
\hline Suspended Substances "SS" $\left(\mathrm{mg} \cdot \mathrm{L}^{-1}\right)$ & Filtration on a Wattman GFC filter & AFNOR, 1999-NF EN 872 \\
\hline Conductivity $(\mu \mathrm{s} / \mathrm{Cm})$ & Conductivity meter & HI86303 \\
\hline Heavy metals $(\mathrm{Zn}, \mathrm{Al}, \mathrm{Fe}, \mathrm{Cu})\left(\mathrm{mg} \cdot \mathrm{L}^{-1}\right)$ & Spectrophotometry with standard kits & WTW Spectroflex 6100 \\
\hline $\mathrm{Cr}^{6+}$ & Automatic titrator & HI900 series titration systems \\
\hline
\end{tabular}

Table 2. Characteristics of the raw effluent

\begin{tabular}{|l|c|c|}
\hline \multicolumn{1}{|c|}{ Parameters } & Values & $\begin{array}{c}\text { Moroccan limit value of dumping of the surface treatment industry } \\
\text { (AVLRBG, 2010) }\end{array}$ \\
\hline $\mathrm{pH}$ & 3 & $6-6,8$ \\
\hline Temperature $\left({ }^{\circ} \mathrm{C}\right)$ & 25 & $\leq 30$ \\
\hline Conductivity $(\mu \mathrm{s} / \mathrm{Cm})$ & 4560 & 2700 \\
\hline $\mathrm{COD}(\mathrm{mg} / \mathrm{l})$ & 587 & 500 \\
\hline Turbidity $(\mathrm{NTU})$ & 98 & 30 \\
\hline Suspended Substances $« \mathrm{SS}(\mathrm{mg} / \mathrm{l})$ & 663 & 50 \\
\hline $\mathrm{Cr}{ }^{6+}(\mathrm{mg} / \mathrm{l})$ & 10020 & 0,1 \\
\hline $\mathrm{Zn}(\mathrm{mg} / \mathrm{l})$ & 4.91 & 10 \\
\hline $\mathrm{Al}(\mathrm{mg} / \mathrm{l})$ & 1.8 & 10 \\
\hline $\mathrm{Fe}(\mathrm{mg} / \mathrm{l})$ & 4.83 & 20 \\
\hline $\mathrm{Cu}(\mathrm{mg} / \mathrm{l})$ & 1.47 & 4 \\
\hline
\end{tabular}

\section{Effects of physicochemical parameters on the electrocoagulation process}

\section{Effect of $p H$}

It has been established in previous studies that $\mathrm{pH}$ has a considerable effect on the efficiency of the electrocoagulation process (Sharma et al.,2021). Moreover, as observed by other investigators (Igwegbe et al., 2021) it was found that the $\mathrm{pH}$ of the medium changed during the process depending on the type of electrode material used and the initial $\mathrm{pH}$. The performance of electrocoagulation process is known and performs an important role in the removal efficiency of pollutants (Madi et al., 2019; Tchamangoa, 2018). In this first experiment, the $\mathrm{pH}$ adjustments were made using $1 \mathrm{~N}$ $\mathrm{NaOH}$ or $\mathrm{HCl}$ solutions under an initial current intensity of $5.7 \mathrm{~A}$. The choice of current intensity referred to previous work, in particular that of Bazrafshan et al. (2015) who obtained a good treatment efficiency by electrocoagulation with a current intensity of $5 \mathrm{~A}$ or those of Parsa et al. (2011) at 6.329 A.

The removal of chromium, COD, suspended solids, conductivity, turbidity and heavy metals with aluminium electrode using different $\mathrm{pH}$ is illustrated in Figures 3 and 4.

According to the results obtained, the elimination rates of the targeted pollutants gradually increase with the time of treatment and prove to be higher at $\mathrm{pH} 7$ than for the other $\mathrm{pH}$. These rates reach, after 60 minutes of treatment, $91.12 \%$ for the turbidity, $76.82 \%$ for the COD, $76.82 \%$ for conductivity, $77.54 \%$ for the SS, $86.82 \%$ for chromium and $90 \%$ for cooper.

These elimination rates recorded during the conducted experiment agree with those reported by Secula et al. (2012) and Gomathi et al. (2011) who, under the same $\mathrm{pH}$ conditions, obtained a good percentage of elimination of sulphates $(97 \%)$ and SS matter $(80 \%)$. This result would be linked to an influence of the $\mathrm{pH}$ on the state of solubility of the products formed and on other species in solution. Indeed, it has been proven that this parameter has an effect on the dissolution of the electrodes (Al Anbari et al. (2012); Zaroual et al. (2006) at pH 6.8. This result agrees with the previously published works (Fayad, 2018; Tezcan,2015) and suggests that electrocoagulation can act as a $\mathrm{pH}$ buffer. 


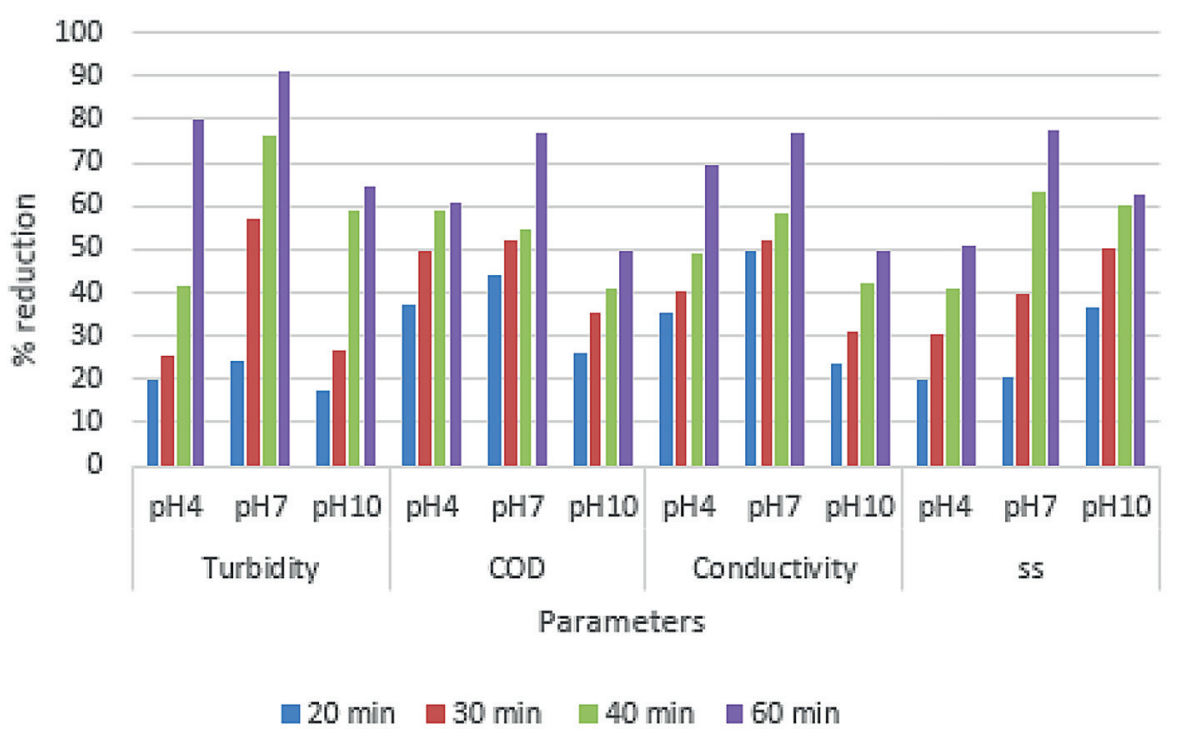

Fig. 3. Effect of $\mathrm{pH}$ on the reduction rate of Turbidity, COD, Conductivity and SS of effluents treated at 5.7 A

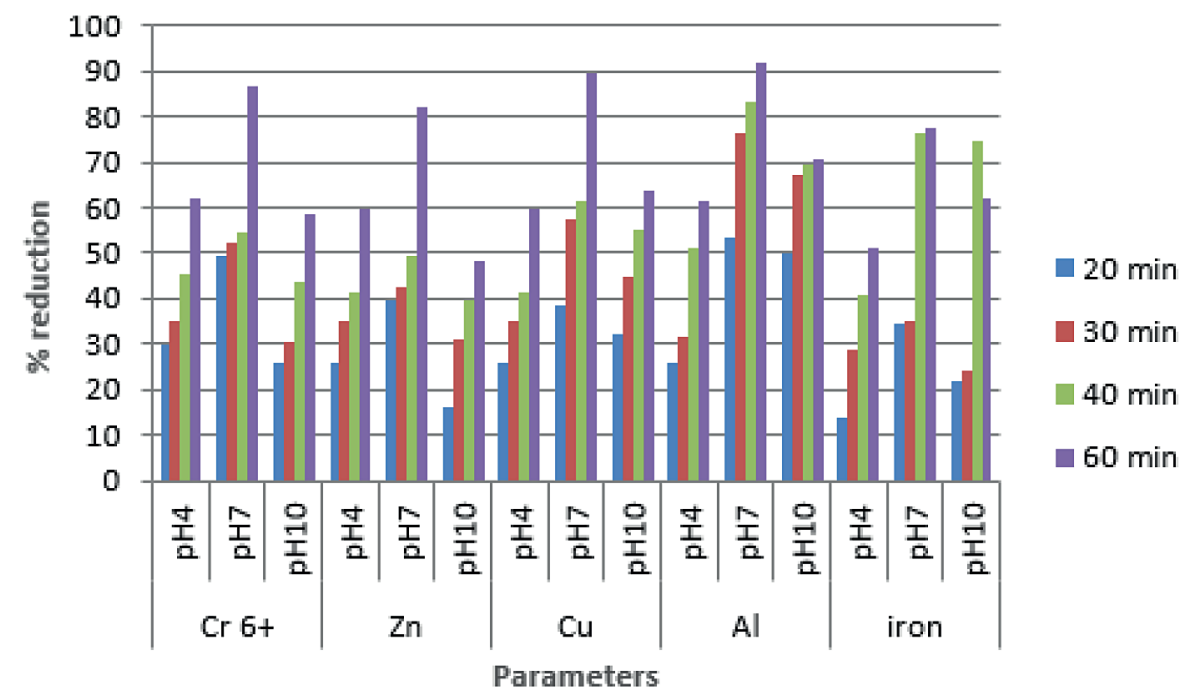

Fig. 4. Effect of $\mathrm{pH}$ on the reduction rate of heavy metals of the effluents treated at $5.7 \mathrm{~A}$

\section{Effect of current intensity}

In order to determine the optimum current intensity to the removal percentage of different pollution parameters: COD, conductivity, turbidity, suspended substances and heavy metals $(\mathrm{Cr}, \mathrm{Zn}$, $\mathrm{Al}, \mathrm{Fe}, \mathrm{Cu}$ ) in the studied effluent, the experiments were carried out at $\mathrm{pH} 7$ and at different intensities 2.8A, 5.7A and 8.6 A. The results obtained (Figures 5 and 6) show that the rate of abatement of pollutants in treated effluents increases along with intensity and treatment duration. These rates reach, after 60 minutes and at a current intensity of 8.6 A, up to $97.12 \%$ for turbidity, $97.5 \%$ for COD, $97.84 \%$ for SS and $96.82 \%$ for conductivity. Similarly, high reduction rates are recorded for metal pollutants, particularly chromium and iron, reaching up to $99.9 \%$ after 60 minutes of processing and under a current intensity of 8.6 A.

The results obtained from the conducted experiments, in particular with regard to metallic contaminants, are consistent with those obtained by several authors. Chen et al. (2004) and Adhoum et al., (2004) reported that the effectiveness of treatment, by electrocoagulation, is mainly affected by current intensity. They showed that certain metal-based dyes are eliminated at $98.5 \%$ with an increase in the current voltage. At the same time, metal ions decreased in the treated effluent with removal efficiency of $99 \%, 99 \%$ and $83 \%$ for $\mathrm{Cu}^{2+}, \mathrm{Zn}^{2+}$ and $\mathrm{Cr}^{6+}$, respectively. Finally, the results obtained by Parsa et al. (2011) go in 


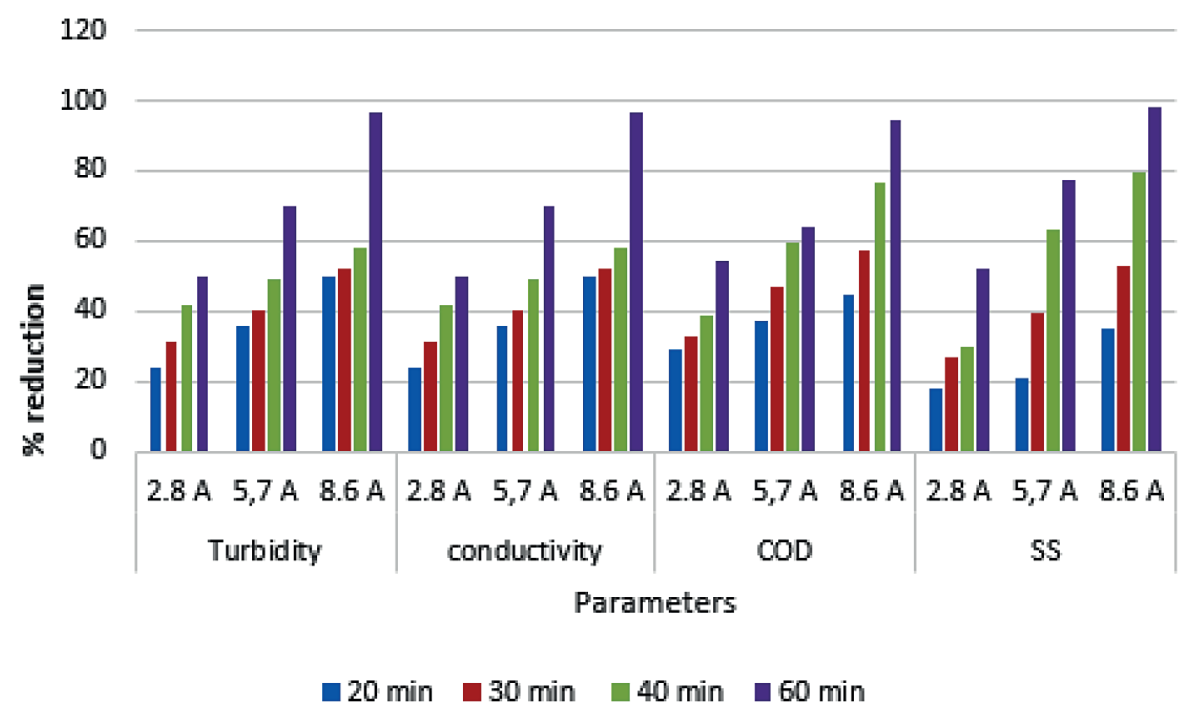

Fig. 5. Effect of current intensity on the reduction rate of Turbidity, DCO, Conductivity and SS of effluents treated at $\mathrm{pH} 7$

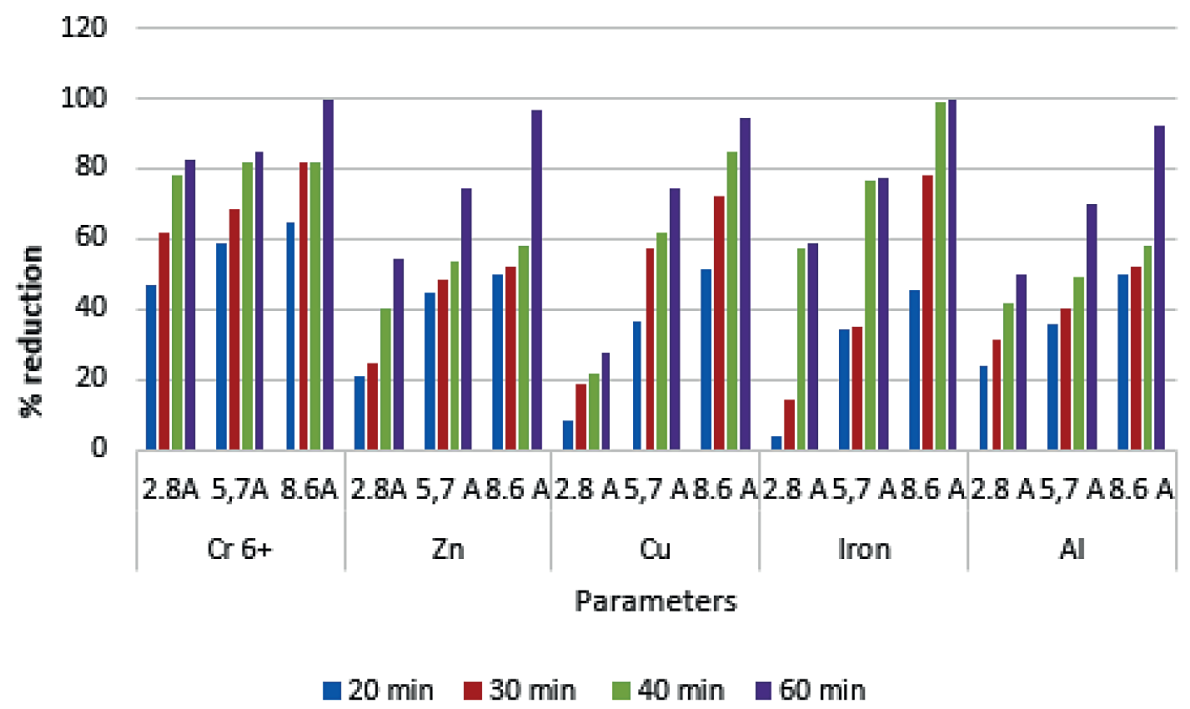

Fig. 6. Effect of current intensity on the reduction rate of heavy metals of effluents treated at $\mathrm{pH} 7$

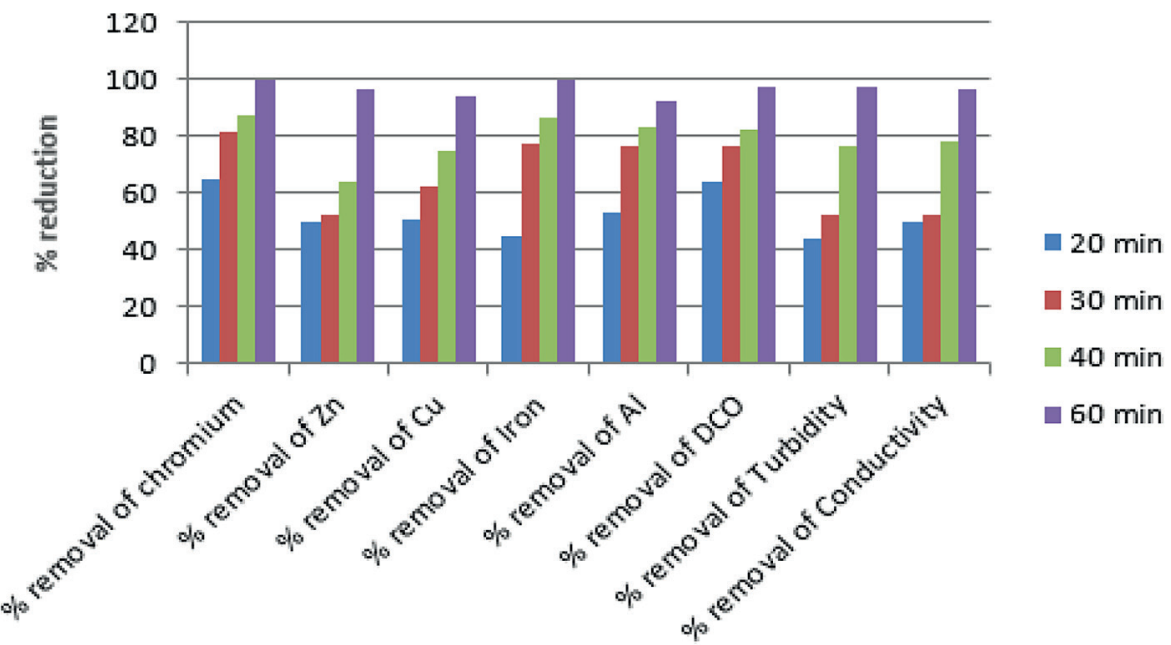

Fig. 7. Effect of processing time under optimal $\mathrm{pH}$ and current intensity conditions ( $\mathrm{I}=8.6 \mathrm{~A}$ and $\mathrm{pH}$ 7) 
Table 3. Physicochemical results of the treated wastewater under optimal electrocoagulation conditions and their reduction.

\begin{tabular}{|l|c|c|c|c|}
\hline \multicolumn{1}{|c|}{ Parameters } & $\begin{array}{c}\text { Raw wastewater } \\
\text { values }\end{array}$ & $\begin{array}{c}\text { Waste water treated by } \\
\text { electrocoagulation }\end{array}$ & Abatement (\%) & $\begin{array}{c}\text { Moroccan limit value of dumping } \\
\text { of the surface treatment industry } \\
\text { (AVLRBG, 2010) }\end{array}$ \\
\hline Conductivity $(\mu \mathrm{s} / \mathrm{cm})$ & 4560 & 145.08 & 96.82 & 2700 \\
\hline $\mathrm{SS}(\mathrm{mg} / \mathrm{l})$ & 663 & 18.96 & 97.15 & 50 \\
\hline Turbidity $(\mathrm{NTU})$ & 98 & 2.82 & 97.12 & 30 \\
\hline $\mathrm{COD}(\mathrm{mg} / \mathrm{l})$ & 587 & 17.31 & 97.05 & 500 \\
\hline $\mathrm{Cr}{ }^{6+}(\mathrm{mg} / \mathrm{l})$ & 10020 & 0.01 & 99.9 & 0.2 \\
\hline $\mathrm{Zn}(\mathrm{mg} / \mathrm{l})$ & 4.91 & 0.15 & 96.82 & 10 \\
\hline $\mathrm{Al}(\mathrm{mg} / \mathrm{l})$ & 1.8 & 0.144 & 91.96 & 10 \\
\hline $\mathrm{Fe}(\mathrm{mg} / \mathrm{l})$ & 4.83 & 0.004 & 99.9 & 20 \\
\hline $\mathrm{Cu}(\mathrm{mg} / \mathrm{l})$ & 1.47 & 0.083 & 94.3 & 4 \\
\hline
\end{tabular}

the same direction with a removal efficiency of up to $91 \%$ for $\mathrm{Cr}^{6+}$ under optimal conditions of $6.329 \mathrm{~A}$ and a treatment time of $18 \mathrm{~min}$.

\section{Effect of processing time under optimal $\mathrm{pH}$ and current intensity conditions}

The effectiveness of the removal of pollutants during electrocoagulation (EC) also depends on the duration of the treatment. Indeed, previous studies showed that the pollutant removal efficiency increases along with the EC time (Castañeda-Díaz et al., 2018; Hakizimana et al., 2017). In this third series of experiments, the optimum conditions of $\mathrm{pH} 7$ and current intensity of 8.6A were ensured, whereas the treatment time varied between $20 \mathrm{mn}, 30 \mathrm{mn}, 40 \mathrm{mn}$ and $60 \mathrm{mn}$.

The results obtained (Figure 7) show a significant increase in the abatement rate of the different pollutants when there is an extension of EC treatment time. For example, after 60 minutes of application of this technique, the elimination rates reached quite high values for global pollutants $(97.5 \%$ for COD, $97.84 \%$ for SS, $97.12 \%$ for turbidity, $96.82 \%$ for conductivity) and metallic contaminants (up to $99.99 \%$ for $\mathrm{Cr}$ and $\mathrm{Fe}, 96.82 \%$ for $\mathrm{Zn}, 94.3 \%$ for $\mathrm{Cu}$ and $91.96 \%$ for $\mathrm{Al})$. An increase in the operating time from 20 to $60 \mathrm{~min}$ in the treatment of the studied industrial wastewater by electrocoagulation has led to increase in the removal efficiencies of various pollutants: heavy metals, COD, turbidity, conductivity and suspended solids. These results are in agreement with the previous research, Tezcan and Eren (2015) achieved the highest removal percentages for $\mathrm{Cd}, \mathrm{Ni}$ and $\mathrm{Cu}$ with $99.78 \%, 99.98 \%, 98.90 \%$ respectively, with a current intensity of $30 \mathrm{~mA} / \mathrm{cm}^{2}$, a $\mathrm{pH}$ of
7 and 90 minutes of electrocoagulation operation. Bazrafshan et al. (2015) determined that the percentage of chromium removal increased from $91 \%$ to $96 \%$, as long as the treatment was between 20 and 60 minutes at $\mathrm{pH} 4$ with a current intensity of $5 \mathrm{~A}$.

The results of the physicochemical analysis of the water treated under optimal conditions show that the values of all the parameters exhibit significant reduction rates of up to $99.9 \%$ (Table 3). At the same time, all the levels recorded for the other parameters remain well below the discharge limit values specific to the surface treatment industries (AVLRBG, 2010). Furthermore, adjusting the $\mathrm{pH}$ to a value of 7, allowed conforming this parameter to these same limit values and optimizing the $\mathrm{EC}$ conditions.

\section{CONCLUSIONS}

The analysis of raw effluents from the surface treatment chain of an aeronautical industry revealed a significant overall load (COD, SS and Turbidity) and in metals ( $\mathrm{Zn}, \mathrm{Al}, \mathrm{Fe}, \mathrm{Cu}$ and $\mathrm{Cr}$ ) exceeding the limit values stipulated by the Moroccan standard specific to surface treatment discharges.

In this regard, an experimental process of electrocoagulation treatment was applied to its wastewater under different $\mathrm{pH}$, current intensity and treatment time conditions. The results showed that the best rates of reduction of chromium (99.9\%), Zn (96.82\%), Cu (94.3\%), iron (99.9\%), Al (91.96\%), DCO (97.5\%), SS (97.84\%) turbidity $(97.12 \%)$ and conductivity (98\%) are obtained under the optimum conditions of $\mathrm{pH} 7$, a current intensity of $8.6 \mathrm{~A}$ and a reaction time of 
60 minutes. At the same time, electrocoagulation allowed the recovery of treated water that largely met the limit values recommended by the Moroccan standards for surface-industry discharges. However, this treatment unfortunately generates sludge which must be studied, treated and highly valued for a zero discharge objective.

\section{REFERENCES}

1. Adhoum N., Monser L., Bellakhal N., Belgaied JE. 2004. Treatment of electroplating wastewater containing $\mathrm{Cu}^{2+}, \mathrm{Zn}^{2+}$ and $\mathrm{Cr}$ (VI) by electrocoagulation. Journal of Hazardous Materials B112, 207-213

2. Ayah M., Grybos M., Tampo L., Bawa LM., Bril H. 2015. Qualité Et Pollution Des Eaux D’un Hydrosystème Littoral Tropical: Cas Du Système Lagunaire De Lomé, Togo. European Scientific Journal 15(11), 95-119.

3. Al Anbari R.H., Alfatlawi S.M., Albaidhani J.H. 2012. Removal of Some Heavy Metals by Electrocoagulation Advanced Materials Research 468-471, 2882-2890.

4. Order setting specific limit values for the rejection of the hot-dip galvanizing branch under the activity of surface treatment. AVLRBG. 2010. Official bulletin No. 5836 - 21 joumada I 1431.

5. Balark D., Chandrika K., Attaolahi M. 2019. Assessment of Effective Operational Parameters on Removal of Amoxicillin from Synthetic Wastewater Using Electrocoagulation Process. Journal of Pharmaceutical Research International 29(1), 1-8, 2019; Article No. JPRI.50457.

6. Bazrafshan E., Leili M., Ansari-Moghaddam A. and Mahvi A.H. 2015. Heavy metals removal from aqueous environments by electrocoagulation process-a systematic review Journal of Environmental Health Science \& Engineering.

7. Bouderka N., Kacem SA., Lakhili F., Lahrach A., Benabdelhadi M. 2016. L'impact De La Pollution Agricole Sur La Qualité Des Eaux Souterraines De La Nappe Du Gharb. European Scientific Journal 11(12), 509-524.

8. Brignon J.M., Gouzy A. 2015. Chrome et ses composés ineris - DRC-14-136881-07003A Version avril 15

9. Bejjany B., Lekhlif B., Eddaqaq F., Dani A., Mellouk H., Digua K. 2017. Treatment of the surface water by Electrocoagulation Electroflotation process in internal loop airlift reactor: Conductivity effect on turbidity removal and energy consumption. JMES, 8(8), 2757-2768.

10. Bejjany B., Lekhlif B. 2017. Treatment of the surface water by Electrocoagulation-Electroflotation process in internal loop airlift reactor: Conductivity effect on turbidity removal and energy consumption. JMES, 8(8), 2757-2768.

11. Bharath M., Krishna B. M. and Manoj Kumar B. 2018. A Review of Electrocoagulation Process for Wastewater Treatment International Journal of ChemTech Research. CODEN (USA): IJCRGG, 11(3), 289-302.

12. Crini G., Lichtfouse E. 2019. Advantages and disadvantages of techniques used for wastewater treatment. Hal archives-ouvertes. Environmental Chemistry Letters 17, 145-155. https://doi.org/10.1007/ s10311-018-0785-9.

13. Copra A.K., Sharma A.K. 2012. Removal of turbidity, COD and BOD from secondarily treated sewage water by electrolytic treatment. Water Science 3(1), 125-132.

14. Igwegbe C.A., Onukwuli O.D., Ighalo J.O., Umembamalu C.J. 2021. Electrocoagulation-flocculation of aquaculture effluent using hybrid iron and aluminium electrodes: A comparative study Chemical Engineering. Journal Advances 6, 100107.

15. Chen G. 2004. Electrochemical technologies in wastewater treatment, Sep. Purif. Technol. 38, 11-41.

16. Dindas G.B., Caliskan Y., Celebi E.E., Tekbas M., Bektas, N., Yatmaz H.C. 2020. Treatment of pharmaceutical wastewater by combination of electrocoagulation, electro-fenton and photocatalytic oxidation processes. J. Environ. Chem. Eng. 8, 103777.

17. Euvrard E. 2017. Substances dangereuses dans les effluents de traitement de surface : identification et traitement par des procédés innovants https://tel. archives-ouvertes.fr/tel-01532206

18. El-Naas M.H., Al-Zuhair S., Al-Lobaney A. 2013. Treatment of petroleum refinery wastewater by continuous electrocoagulation, International Journal of Engineering Research and Technology. IJERT, 2(10), 2144-2150.

19. Fayad N. 2018. The application of electrocoagulation process for wastewater treatment and for the separation and purification of biological. Chemical and Process Engineering. Université Clermont Auvergne, 2017. English. NNT: 2017CLFAC024 p207. archives-ouvertes 5, 6-11.

20. Gomathi, P., Ramamurthi, V., Anand, P. 2011. Degradation Studies of Tannery Effluents using Electro Flotation Technique J Chem Eng Process Technol 2, 1.

21. Izougarhane M., Mansouri D., El Ibaoui H., Chakiri, S., Fadli, M. 2016. Physico-Chimie Et Teneurs Metalliques Des Eaux De L'estuaire De L'oued Sebou Durant Des Années De Dragage Du Sable/ 2007, 2014, 2015, 2016. European Scientific Journal 30(12), 127-147.

22. Castañeda-Díaz J., Pavón-Silva T., Gutiérrez-Segura E., and Colín-Cruz A. 2018. ElectrocoagulationAdsorption to Remove Anionic and Cationic Dyes 
from Aqueous Solution by PV-Energy. Journal of Chemistry, Article ID 5184590, pp. 14.

23. Nepo Hakizimana J., Gourich B., Chafi M., Stiriba Y., Vial C., Drogui P., Naja J. 2017. Electrocoagulation process in water treatment: A review of electrocoagulation modeling approaches Desalination 404, 1-21.

24. Basiri Parsa J., Rezaei Vahidian H., Soleymani A.R., Abbasi M. 2011. Removal of Acid Brown 14 in aqueous media by electrocoagulation: Optimization parameters and minimizing of energy consumption. Journal Desalination 278, 295-302.

25. Madi K., Yahiaoui I., Aissani-Benissad F., Vial C., Audonnet F., Favier L. 2019. Basic red dye removal by coupling electrocoagulation process with biological treatment. Environmental Engineering and Management Journal, 18(3), 563-573.

26. Sharma L., Prabhakar S., Tiwari V., Dhar A., Halder A. 2021. Optimization of EC parameters using $\mathrm{Fe}$ and $\mathrm{Al}$ electrodes for hydrogen production and wastewater treatment Environmental. Journal Advances 3, 100029.

27. Mickova I. 2015. Advanced electrochemical technologies in wastewater treatment Part I: Electrocoagulation American scientific research journal for engineering. Technology and Sciences 14(2), 233-257.

28. Suryaningsih N., Widayatno T., Sugiharto A. and Fuadi A.M. 2021. The Effectivity of Aluminum Electrode for River Water Purification Using Electrocoagulation. Materials Science and Engineering IOP Conf. Ser.: Mater. Sci. Eng. 1053012130.

29. Alam R., Sheob M., Saeed B., Khan S.U., Shirinkar M., Frontistis Z., Basheer F. and Farooqi I.H. 2021. Use of Electrocoagulation for Treatment of Pharmaceutical Compounds in Water/Wastewater: A Review Exploring Opportunities and Challenges. Water 13, 2105. https://doi.org/10.3390/w13152105

30. Baby R., Saifullah B. and Hussein M.Z. 2019. Carbon Nanomaterials for the Treatment of Heavy Metal-Contaminated Water and Environmental Remediation. Nanoscale Research Letters, 14, 341. https://doi.org/10.1186/s11671-019-3167-8

31. Rusdianasari Bow Y., Dewi T. 2019. Peat Water
Treatment by Electrocoagulation using Aluminium Electrodes. Earth and Environmental Science, 1-9.

32. Siba A., Eljaafari S., Mokhtari F. 2018. Pollution Bactérienne Et Toxique Dans Les Eaux De Rejets Industriels Et Domestiques Du Littoral Atlantique (Casablanca Est- Maroc). European Scientific Journal 12(14), 283-296.

33. Jerroumi S., Ngala S., Lekhlif B., Jamal J.E., Lakhdar M., Afrine L. 2019. Investigation of electrocoagulation on the removal of nickel in waste water from an electroplating bath using aluminum and iron electrodes. Mor. J. Chem. 7(4), 727-738.

34. Tchamangoa S.R., Darchena A. 2018. Investigation and optimization of a new electrocoagulation reactor with orizontal bipolar electrodes: Effect of electrode structure on the reactor performances. Journal of Environmental Chemical Engineering, pp. 37. DOI: 10.1016/j.jece.2018.06.044

35. Secula M.S., Igor I. 2012. Electrocoagulation treatment of sulfide wastewater in a batch reactor: Effect of electrode material on electrical operating costs. Research Gate 11(8), 1485-1491.

36. Foudhaili T. 2019. Traitement de la salinité sulfatée et de la toxicité associée des effluents miniers au moyen de l'électrocoagulation. Ecole Polytechnique, Montreal (Canada), ProQuest Dissertations Publishing, 244, 28728132.

37. Tezcan U., Eren Ö. 2015. A Removal of Heavy Metals (Cd, Cu, Ni) by Electrocoagulation https://www. researchgate.net/publication/269404945.

38. Roland Bako Y.F., Zongo I., Karanga Y., Tapsoba I., Sawadogo I. et Baga B. 2021. Etude des paramètres opératoires d'électrocoagulation pour le traitement d'un effluent de textile: Exemple du bleu de méthylène, Int. J. Biol. Chem. Sci. 15(2), 790-802.

39. Swadi Tlaiaa Y., Abdul Razaq Naser Z., Hassoon Ali A. 2020. Comparison between coagulation and electrocoagulation processes for the removal of reactive black dye RB-5 and COD reduction. Desalination and Water Treatment 195, 154-161.

40. Zaroual Z., Azzi M., Saib N., Chainet E. 2006. Contribution to the study of electrocoagulation mechanism in basic textile effluent. Journal of Hazardous Materials B131, 73-78. 